University of California, Hastings College of the Law UC Hastings Scholarship Repository

Faculty Scholarship

2002

\title{
Using History to Inform Political Participation in a California History Course
}

David Takacs

UC Hastings College of the Law, takacsd@uchastings.edu

Gerald Shenk

Follow this and additional works at: http://repository.uchastings.edu/faculty_scholarship

Part of the Curriculum and Instruction Commons, and the History Commons

\section{Recommended Citation}

David Takacs and Gerald Shenk, Using History to Inform Political Participation in a California History Course, 84 Radical Hist. Rev. 138 (2002).

Available at: http://repository.uchastings.edu/faculty_scholarship/1265

This Article is brought to you for free and open access by UC Hastings Scholarship Repository. It has been accepted for inclusion in Faculty Scholarship by an authorized administrator of UC Hastings Scholarship Repository. For more information, please contact marcusc@uchastings.edu. 


\title{
Using History to Inform Political Participation in a California History Course
}

\author{
Gerald Shenk and David Takacs
}

$\mathrm{O}$ torically informed, self-aware members of their chosen communities. Inspired by the teachings of Paolo Freire, we have been developing a "praxis pedagogy."1 We believe that when students take action in their communities — action guided by ethical self-reflection and a careful study of history — they become more aware of their connections to others and of their roles and responsibilities as historical actors. As a result, we believe they become more committed to social justice and environmental stewardship.

In praxis pedagogy, the scholar facilitates a process that results in a radical expansion of knowledge. When we see students as knowledge generators, we help them transgress the boundaries of their known worlds. As bell hooks describes it, "Freire's work affirmed that educators can only be liberatory when everyone claims knowledge as a field in which we all labor."2 All students bring to our classrooms what hooks calls the "authority of experience" (89). Each student has lived under a particular set of circumstances; all have experienced the world in a unique way and are uniquely poised to generate new observations and make new connections. In this assets model, teaching is then designed to help new knowledge blossom, knowledge that seeps into the "real world" in ways we may never know.

This assets model fits our seven-year-old campus, California State University Monterey Bay (CSUMB). Rising from the ruins of Fort Ord, a decommissioned military base just east of Monterey, our educational program is explicit about its com-

Radical History Review

Issue 84 (fall 2002): $138-48$

Copyright 2002 by MARHO: The Radical Historians' Organization, Inc.

138 
mitments to multiculturalism and social justice. The mission of the university is "to build a multicultural learning community founded on academic excellence from which all partners in the educational process emerge prepared to contribute productively, responsibly, and ethically to California and the global community." Our vision statement commits us to "be distinctive in serving the diverse people of California, especially the working class and historically undereducated and low-income populations." About a third of CSUMB's students are Latino/Latina; many of our students are first-generation college students. Our students are, in general, talented, motivated, and a joy to work with.

We coteach a course in the social and environmental history of California that spans five hundred years. We ask our students to analyze how the relationships between groups of people and between people and the earth have developed over this period. By looking at these relationships, we hope that students learn about their own relationships with each other and with the earth. We share a conviction that many of the injustices in our society are rooted in the history of how Europeans and white Americans have exploited and distributed the resources of the earth. In other words, we believe that social problems are always at some level also environmental problems. Conversely, we hope that our students come to understand that work on environmental issues inherently demands attention to social issues. History, we believe, is not relegated to the past. In our teaching, we see historical understanding as a foundation that helps students become more effective actors in their communities. When they've named an issue of personal political concern - the threats that pesticides pose to community well-being, say, or the dangers that tampons pose to women's health and the environment—students may use history to help them understand how they come to find themselves in this situation, and what they might do to change their communities.

In our class, students have campaigned for an Urban Growth Boundary in a neighboring city; helped organic farmers market their products on campus; educated their soccer team about presidential candidates' positions; organized the campus Dia de los Muertos celebration; published an art and politics 'zine; and participated in dozens of other projects in their neighborhood, academic, ecological, spiritual, familial, and collegiate communities. They did this as part of the centerpiece of the course, the Historically Informed Political Project (HIPP). We believe that any activity is political if it affects how people in a society govern themselves. In this class, we invite students to embark on a political project reflecting their personal values and assumptions about the world they live in. This course requires that their political project engage with a California issue that has both environmental and social dimensions. They conduct historical research helping them understand the background of their project, describe the values and assumptions they carry into the project, conduct the project itself (investing at least ten hours in their political work), 
make a set of policy recommendations informed by both their historical research and their community experience, and reflect on how their values and assumptions change as a result of engaging in the project.

The HIPP, and the student work that comes from it, embody our broader agenda as we are developing and testing the efficacy of what we call praxis pedagogy. We are searching for more effective ways for students to connect their learning to meaningful citizenship in a diverse democracy. We see the praxis process as a cycle of self-reflection, study and discussion, and purposeful action, leading to more selfreflection. In the self-reflection stage, students think about their own identities and what their past actions tell them about themselves. They use this personal history to identify the values that matter most to them and explore what assumptions these values are based on. In the study and discussion phase, we ask them to read, collaborate with peers, and conduct independent research that will help them think more deeply about their values and assumptions, about the subject matter with which they are engaged, and about what political and social processes may sustain their beliefs and the subject matter. They then reevaluate these values and assumptions in light of their study. We ask them, further, to use the study phase to help them think about issues of justice and the ways their personal choices may implicate them in the perpetuation of injustices, and to use their new understandings to become intentional participants in the civic lives of their communities.

The action stage necessarily follows careful self-reflection and conscientious study. We value the action stage both for what we believe it can contribute to greater equity and justice in the world and for what we think is a more effective and significant way for students to connect their learning to meaningful citizenship in a diverse democracy. When doing political projects, students may bring their knowledge to their chosen communities. Simultaneously, they learn from all with whom they work - schoolchildren, farmworkers, agency directors, and so on. Knowledge synergistically emerges from their interactions, knowledge that students bring back into the classroom community and into whatever other community in which they find themselves in the future. The community is enlivened by this new knowledge, and, we believe, so are the students.

Each new praxis cycle should make students more thoughtful, ethical, and effective citizens whose public and private acts are informed by a more sophisticated and self-reflective understanding of the disciplines they are studying.

As fellows in the Carnegie Academy for the Scholarship of Teaching and Learning, we have been analyzing the student work that results from this experience. We are finding that students develop a more sophisticated understanding of themselves as political actors; acquire a more nuanced understanding of specific details about their issues and communities; feel more empowered about making a difference in the world; understand and use the tools of political action; express a desire to make more of a difference in their communities; demonstrate a commit- 
ment to making such a difference; show a more complex understanding of themselves as community members; and exhibit a more sophisticated understanding of the connection between values, service, and politics. If we do our job well, students will use history to empower themselves to act with care and love in collaboration with others to improve their communities.

Below is our Historically Informed Political Project guide for Spring 2002. Students submit a portion of their HIPP each week, and we return their writing the following week with comments. We also encourage them to rely on each other as peer reviewers. Students find the HIPP difficult, overwhelming, but, ultimately, exciting.

\section{READINGS}

\section{Books}

Frank Bardacke, Good Liberals and Great Blue Herons (Santa Cruz, CA: Center for Political Ecology, 1993).

Patricia Nelson Limerick, Something in the Soil: Legacies and Reckonings in the New West (New York: Norton, 2000).

Carolyn Merchant, ed., Green versus Gold: Sources in Environmental History (Washington, DC: Island, 1998).

John Steinbeck, The Harvest Gypsies: On the Road to the Grapes of Wrath (Berkeley, CA: Heyday, 1988).

\section{Articles}

Gray Brechin, "Preface” and "Water Mains and Bloodlines," in Imperial San Francisco: Urban Power, Earthly Ruin (Berkeley: University of California Press, 1999).

Kitty Calavita, excerpts from Inside the State: The Bracero Program, Immigration, and the I.R.S. (New York: Routledge, 1992).

Mike Davis, “The Case for Letting Malibu Burn," in Ecology of Fear: Los Angeles and the Imagination of Disaster (New York: Metropolitan, 1998), 93-147.

Robert F. Heizer and Alan J. Almquist, "Constitutional Debate on Race and Rights, 1849," and "The People v. Hall, Oct. 1, 1854" in The Other Californians: Prejudice and Discrimination under Spain, Mexico, and the United States to 1920 (Berkeley: University of California Press, 1971). 92-119, 229-34.

William Issel, “'Land Values, Human Values, and the Preservation of the City's Treasured Appearance,' Environmentalism, Politics, and the San Francisco Freeway Revolt,” Pacific Historical Review 68.4 (1999): 611-45.

Susan Johnson, "Bulls, Bears, and Dancing Boys: Race, Gender, and Leisure in the California Gold Rush," Radical History Review 6o (1994): 5-37.

Glenna Matthews, “The Los Angeles of the North: San Jose's Transition from Fruit Capital to High Tech Metropolis," Journal of Urban History 25.4 (1999): 459-76.

Don Mitchell, "Labor and Landscape: The Wheatland Riot and Progressive State Intervention," in The Lie of the Land: Migrant Workers and the California Landscape (Minneapolis: University of Minnesota Press, 1996), 36-57. 
Douglas Monroy, "Brutal Appetites," in Thrown among Strangers: The Making of Mexican Culture in Frontier California (Berkeley: University of California Press, 1990), 51-96.

Mark Spence, "Dispossessing the Wilderness: Yosemite Indians and the National Park Ideal, 1864-1930," Pacific Historical Review 65.1 (1996): 27-6o.

Susan Stryker and Jim Van Buskirk, excerpts from Gay by the Bay: A History of Queer Culture in the San Francisco Bay Area (San Francisco: Chronicle, 1996).

"Understanding the Riots: Los Angeles before and after the Rodney King Case," Los Angeles Times, November 19, 1992, special section.

\section{ASSIGNMENTS}

\section{Monday, February 4: Observing Connections/Thinking about History (3 points)}

In this assignment, we are asking you to observe and to think about how your observations might teach you something about history. We would like you to begin making systemic connections between yourself, the landscape around you, and the people around you. While the explicit connections you make about your site won't necessarily appear in your HIPP, your considerations about "history" might.

1. Before you go out on your field trip, we would like you to answer the following questions: a) What is "history"? b) What is "social history"? c) What is "environmental history"?

2. We would like you to take a field trip (think about carpooling!) to one of the following four sites: a) Fishermen's Wharf in Monterey. There are actually a few Fishermen's Wharves in Monterey; we want you to tour two of them - the one where all the tourists go, and the one to its right/east (as you're facing the tourist pier), a working fishers' wharf. There is public transportation from CSUMB to Fishermen's Wharf. b) Any agricultural field between Fort Ord and Salinas. If you exit the back route off Fort Ord, make a right on Reservation Rd. and make your first left; you'll find plenty of landscapes for contemplation. c) The boardwalk in front of the Inn at Spanish Bay in Pebble Beach. To reach this by public access, go to Asilomar State Beach in Pacific Grove, walk to the south end of the beach, and continue on the boardwalk. You will see Spanish Bay inland from the water. d) Any spot along Cannery Row in Monterey.

Please spend at least one to two hours at your site. We want you to be careful scholars, recording what you see at your sites. What relationships do you see among people? What relationships do you see between people and the landscapes around them? What does the built environment tell you about relationships between people, or about relationships between people and the landscapes around them?

Please feel free to talk with those you find at work and at play, and report back on what you learn. Of course, you should feel free to include any pertinent information that we did not address in our questions here.

3. In a $500-$ to $75^{0}$-word essay (two to three pages), we'd like you to consider these questions: a) What evidence do you see that might help you understand the social and environmental history of this place? b) In particular, what evidence do you see in the 
relationships between people that helps you understand the social history of the people you are studying? c) What evidence do you see in the relationships between people and the landscape that might help you understand the environmental history of this place? d) What evidence do you see in the built environment that helps you understand the social and environmental history of this place?

Your essay should have a thesis statement. That is to say, you should organize your thoughts around one main point that you want your reader to understand. What is the most important idea you came up with as a result of your observations? Use that idea to organize your answers to our questions.

Please include at least one idea from Limerick's book that helps you understand the relationships you've observed.

\section{Monday, February 11: What is politics? (3 points)}

For today, you should have finished Frank Bardacke's Good Liberals and Great Blue

Herons. Frank Bardacke will be visiting us in class to discuss his book and talk about politics.

In a one-page thought piece, please answer the following questions: What is "politics"? What counts as "politics" for you? How does your conception of "politics" differ from Bardacke's? Do you ever act politically? If so, what forms do your political activities take?

\section{Monday, February 18: Defining a Political Project (3 points)}

As described above, the Historically Informed Political Project is the core work for this class. Today's assignment is perhaps the most crucial assignment of the semester, so we ask that you invest sufficient care. Your answers to these questions need not be in the form of an essay. We expect it will take you 500-750 words to answer these questions. Remember: This will be the backbone for the rest of your work this semester.

First, we would like you to revisit your definition of "politics" from last week. Now that you've read and met Bardacke and we have discussed "politics," what counts as "politics" for you?

We would like you now to define the political project you are going to work on (remember, you will be investing a minimum of ten hours of community work) and research during the semester:

a. What is your issue?

b. What is the political project?

c. With what organization will you be working?

d. Why will you be working with them?

e. What specific activities and strategies will you employ?

f. What are your goals for the project?

g. How will the activities and strategies you've chosen help you to achieve your goals?

$\mathrm{h}$. It is not an accident that you've chosen this project. Your personal history shapes your interest in this issue and leads you to pursue your interest in a certain way. Please tell a story from your personal history that helps us understand why this issue is important to you and why you have decided to conduct the project in the way you've named. This personal 
history might be a) an event you participated in; b) something that happened to you; c) a connection to a significant person who has shaped your life; d) some way that your race, economic standing, gender, ethnicity, sexual orientation, religious identity, or some other factor has shaped you; e) any other life experience you've had. Important: We will be sharing these stories in class. While we are asking that you make a personal connection to the political project you've chosen, we are not asking you to divulge anything that would be uncomfortable for a classmate to learn about you.

\section{Monday, February 25: Historical Research Beginnings (3 points)}

Please prepare a one- to two-page proposal for how you will do the historical research that informs your political project. At very least, this will include:

1. A description of the issue you're investigating. You've already chosen a political project connected to some local issue that is important to you. Remind us of what this issue is and what current-day policy relevance this issue has.

2. Explain what kinds of historical sources you will be using to help you understand your issue. What will be pertinent? Where will you look? What kinds of primary documents will you use?

3. Do a brief literature search in the CSUMB library electronic journal indexes under Resources, A-Z, for scholarly references you might use to help you understand and analyze your research topic. Most of these indexes give you the option to select only refereed journals, and to exclude book reviews. (A refereed journal is one where scholars' work is reviewed and approved by their peers before the work is published.) Find three scholarly sources relevant to your topic and provide a complete bibliographic reference to each at the end of your proposal.

4. Please review the contents of Merchant, Limerick, and Bardacke; they contain many, many possible ideas that you might want to investigate and resources you might want to use. Please cite one chapter from Bardacke or one article from Merchant or one essay from Limerick as a useful source for your historical investigations.

5. What is your research question? That is to say, we would like you to state in one to two sentences what is the central question you are trying to answer in your research. This, more likely than not, will eventually lead you to a thesis statement forming the backbone of your essay.

6. Please name at least one theme we have explored thus far in class that you can use to help you illustrate/understand your research question.

\section{Monday, March 4: Laws and the Constitution (3 points)}

No matter what political project you are pursuing, the United States Constitution addresses your issue of concern.

1. Please read the U.S. Constitution and Amendments 1-10 and 14.

2. Please find one law (federal, state, or local) that pertains to your issue and read the text of that law. (It may be that the law is so long and complicated that you will not want to read the entire law. Please read enough so that you understand what the law does and how it pertains to your political issue.) 
3. Please find two items from the U.S. Constitution that help you understand the history of your issue better and explain the connection between the Constitution and your issue.

This is a difficult assignment. If you are struggling with connections between the Constitution and your project, consider some of these hints: Look carefully at the powers given to Congress (article I, section 8, and the Bill of Rights, Amendments 1-10); What does the Constitution say about property? What does it say, specifically, about individual freedoms? Which freedoms does it mention? What does it say, specifically, about equality of opportunity? What does it say about who makes and enforces laws?

\section{Monday, March 11: Social and Environmental Histories/Connecting the Local Outward (3 points)}

First, please read Limerick, "The Gold Rush and the Shaping of the American West," (214-27).

Each of your projects is embedded in multiple social and environmental histories, and each has local, state, and national connections. In a thought piece of about two pages, please:

1. Explain whether your issue is primarily a "social" issue, an "environmental" one, or both.

2. This means you must define clearly what you mean by those terms social and environmental. Please use at least one example from Limerick's essay that will help your reader understand the differences between "environmental" and "social" issues.

3. Explain the "environmental" factors one needs to consider in order to understand the social history of your problem.

4. Explain the "social" factors one needs to consider in order to understand the environmental history of your problem.

5. Explain what aspects of your research and political project are unique to the geographic region in which it occurs. That is to say, what about your project is unique to Monterey County?

6. How does your issue connect to the rest of the state of California? Is anything about your issue unique to the state of California?

7. How is your issue connected to U.S. history beyond California state borders? Again, examples from Limerick's essay will help you explain the connections between local, state, and national histories.

\section{Monday, March 25: Annotated Bibliography (5 points)}

Please prepare an annotated bibliography consisting of at least four secondary sources (not including readings we have done for class) and two primary sources that you will use in your individual research project. By an annotated bibliography, we mean not merely a list of references, but a list where each reference has a brief description of what the reference is about and how it helps you understand your project. A sample annotated bibliography reference for a secondary source might look like this: 
Takacs, David. "Return from Oblivion: The True Story of Sea Otters on the Central Coast of California," in A Long, Long, Long History of the State of California, ed. Gerald Shenk (Monterey, CA: Really Obscure Publishing Company, 2002).

In this article, Takacs traces how various groups of Californians have viewed sea otters as resources during the last two hundred years of the state's history. Once seen only as a source of economic revenue for their valuable fur, otters today are seen as a valuable commodity that attracts thousands of visitors to the area each year. This is important for my research project, as I am attempting to understand why Californians have decided that protection of the sea otter is more important than exploiting them for immediate economic gains.

\section{Monday, April 1: Beautiful Page (3 points)}

For class today, please prepare one beautiful page that could go in your final project. First, we want you to state clearly your research topic and research question. Then, we want you to explain how at least three of the readings we have done so far for class (readings that everyone has read) help you to think about the history of your problem. We would like you to choose readings that help you interpret or understand the context for your historical problem, as opposed to readings that provide factual information about your historical problem. Dedicate one paragraph to each reading. So, this assignment should contain four paragraphs: one where you clearly explain your research topic, and one paragraph each that explains how the reading from class helps you think about your research topic.

For example: Let's say your research project seeks to understand the social and environmental history of how Californians have thought about otters in Monterey Bay. We do not want you to simply pull facts from your readings about when otter hunting started and what date the otters returned to this area. Rather, we would like you to choose readings that help you understand how Californians have thought about (and therefore treated) the nonhuman inhabitants with which we share this land. Among the readings you could choose for this topic would be Genesis, various Indian creation myths from Merchant, Monroy's "Brutal Appetites," Bardacke, various readings from Limerick, and the U.S. Constitution. None of these documents mention otters - but each of them offers a perspective on how California's inhabitants have conceived of themselves as part of, or as apart from, the world around them.

\section{Monday, April 8: Another Beautiful Page (3 points)}

For class today, please prepare another beautiful page or two that could go in your final project. As we did last week, we want you to state clearly your research topic and research question. Then, we want you to explain how at least three of the sources you have chosen that are unique to your project help you to think about the history of your problem. At least one of these sources should be a primary document, and at least one should be a secondary document. We would like you to choose readings that help you interpret or understand the 
context for your historical problem, as opposed to readings that provide factual information about your historical problem. Dedicate one paragraph for each source. So, this assignment should contain four paragraphs: one where you clearly explain your research topic, and one paragraph each that explains the connection between your research project and the source you are using.

\section{Monday, April 22: First Draft of HIPP Essay Due (10 points)}

Yikes! We would like you to submit a polished draft of your final project.

Please refer to the set of outcomes we have listed for the final project. You will find that, if you have been diligently turning in your assignments, you have already completed a draft of nearly all the elements of the essay. (Some of those outcomes we have not asked you to address explicitly yet. You may attempt to address them here, or you may leave them out of this draft without penalty.)

The difficult part here will be tying everything together. It will be crucial that your essay have a thesis statement, some main point that you will use to bring together all your ideas. We will have worked on crafting these statements in class; be sure you have one. In your draft, please indicate what you still need to include in your essay, sort of a "coming attractions" for your attentive reader.

Please note that the more complete your draft, the better the quality of feedback we can provide you. Our past experience indicates that students who invest a lot of effort in this draft invariably produce a finer final product.

\section{Monday, April 29: Political Project Progress Report (3 points)}

By this date, you should be done or nearly done with your political project work. From a two- to three-page thought piece, we would like to know (and this will be part of the final draft of your essay):

1. How did your work go? Please explain exactly what you did to complete your political project work. Did you succeed completely in meeting your goal? Did you fail completely? Something in between? Did your goal change along the way?

2. If you worked with an agency or organization, what did you learn about it? Would you continue your work with it? Why or why not?

3. What did you learn about "politics" and political participation? Did your definition of "politics" change?

4. As a result of this experience, are you more or less likely to participate politically in your communities? Why?

5. Refer back to the values and assumptions about the world you wrote about when you began the course. How have those values and assumptions changed as a result of your political participation? Please explain what about the experience led to these changes; be as explicit as possible about making connections.

6. Please explain how at least two historical themes you have explored in your essay helped you make sense of your political participation. 
148 Radical History Review

Monday, May 6: Policy Recommendations (3 points)

In a thought piece of about two pages (and this should be part of your final essay), please explain:

1. What public policy/policies have you encountered in the course of your political project that you would like to see changed (or that you think work quite well as is)? Who has determined the current policy? Who enforces it?

2. What possible future directions would you like this policy to take and why?

3. How has the historical research you have done led you to suggest these future directions?

4. How has the political work you have done led you to suggest these future directions?

5. How do your biases and assumptions about the world shape the policy recommendations you are making?

6. What have you learned about the Constitution as a result of doing this work? How does the Constitution restrain or facilitate the work you have been doing?

Monday, May 20: Final HIPP Project Due (25 points)

\section{Notes}

1. Paulo Freire, Pedagogy of the Oppressed (New York: Continuum, 1997).

2. bell hooks, Teaching to Transgress: Education as the Practice of Freedom (New York:

Routledge, 1994), 14. 
Copyright $\odot 2002$ EBSCO Publishing 
Copyright $\odot 2003$ EBSCO Publishing 
Copyright of Radical History Review is the property of Duke University Press and its content may not be copied or emailed to multiple sites or posted to a listserv without the copyright holder's express written permission. However, users may print, download, or email articles for individual use. 